УДК 631.526.3:006.83:631.53.01:633.11

(C) 2013

Баган А. В., кандидат сільськогосподарських наук

Полтавська державна аграрна академія

\title{
ВПЛИВ СОРТОВИХ ВЛАСТИВОСТЕЙ НА ПОСІВНІ ЯКОСТІ НАСІННЯ ПШЕНИЦІ ОЗИМОї
}

\section{Рецензент - кандидат сільськогосподарських наук С. В. Філоненко}

\begin{abstract}
Досліджено посівні якості насіння у сортів пшениці озимої різного географічного походження 6 умовах Полтавської області. Вивчено показники чистоти і лабораторної схожості насіння та маси 1000 зерен у досліджуваних сортів. Виділено сорти пшениці озимої Подолянка і Василина за чистотою і схожістю із висококондииійним насінням першої репродукиії. Відмічено за показником маси 1000 зерен сорт Золотоколоса із крупним i вирівняним насінням. Рекомендовано для вирощування у виробничих умовах використання висококондиційного посівного матеріалу пшениці озимої виділених сортів.
\end{abstract}

Ключові слова: пшениия озима, сорт, насіння, посівні якості, чистота, маса 1000 зерен, лабораторна схожість.

Постановка проблеми. Проблема вирощування високоякісного насіння вважається однією 3 найбільш важливих й актуальних для сучасного вітчизняного сільськогосподарського виробництва. Засилля сортів іноземної селекції, що спостерігається нині, можна зменшити не лише шляхом створення вітчизняних високопродуктивних сортів, а й шляхом впровадження високоякісного насіння. Більшість селекціонерів переконані в тому, що потенційні можливості сучасних сортів сільськогосподарських культур щодо їх урожайності не повністю реалізуються внаслідок порушення системи насінництва. Не менш важливим залишається фактор і якості посівного матеріалу. Багатьма дослідженнями стверджується безперечний факт впливу погодних та інших факторів на посівні якості насіння сільськогосподарських культур. Низка вчених пропонують впровадження зонального характеру ведення насінництва [2, 4]. Тому актуальним залишається питання вивчення посівних якостей насіння пшениці озимої залежно від сортових властивостей в умовах Полтавської області.

Аналіз основних досліджень і публікацій, у яких започатковано розв'язання проблеми. Сучасні технології вирощування сільськогосподарських культур, передусім, базуються на використанні високоякісного насіння. Це голов- ний фактор, який може мати безпосередній вплив на подальший ріст рослин, їх репродукційний процес, а відповідно, й на врожай. Не менш важливого значення надається й екологічним факторам, що мають як безпосередній, так і опосередкований вплив на формування насіння. Необхідно також зазначити, що вплив екологічних факторів на чистоту насіння пшениці озимої значно менше залежить від погодних факторів, порівняно 3 організаційними та економічними можливостями сільськогосподарських підприємств $[2,5]$.

Одним із важливих показників посівних властивостей насіння $€$ також маса 1000 насінин, що обумовлений комплексом погодних та агротехнічних факторів [3].

Важлива роль серед посівних властивостей насіння пшениці озимої належить лабораторній схожості, що виступає головним чинником під час віднесення тієї чи іншої партії до кондиційного або ж некондиційного насіння. Даний показник визначається чималою кількістю природних факторів, передусім, рівнем зволоження території та температурним режимом повітря $[1,4]$.

Мета і завдання. Метою досліджень було встановлення рівня формування посівних якостей насіння у сортів пшениці озимої в умовах Полтавської області.

Завдання:

- визначити рівень формування чистоти, маси 1000 зерен і лабораторної схожості насіння у сортів пшениці озимої;

- виділити цінні джерела для вирощування посівного матеріалу пшениці озимої у виробничих умовах Полтавської області

Матеріали і методи досліджень. Матеріалом для досліджень було п'ять сортів пшениці м'якої озимої різного географічного походження: Подолянка, Золотоколоса, Диканька, Василина і Смуглянка. Польові дослідження проводили протягом 2011-2012 pp. на території сільськогосподарських підприємств Миргородського району Полтавської області. 
Посівні якості насіння пшениці озимої, 2011-2012 рр.

\begin{tabular}{|c|c|c|c|c|c|c|}
\hline \multirow{2}{*}{ Сорт } & \multicolumn{2}{|c|}{ Чистота, \% } & \multicolumn{2}{c|}{ Маса 1000 зерен, г } & \multicolumn{2}{c|}{ Схожість, \% } \\
\cline { 2 - 7 } & 2011 р. & 2012 p. & 2011 p. & $2012 \mathrm{p}$. & 2011 p. & 2012 p. \\
\hline Подолянка & 99,8 & 99,2 & 42,9 & 40,8 & 93,7 & 93,2 \\
\hline Золотоколоса & 99,6 & 98,9 & 44,4 & 41,7 & 94,4 & 93,8 \\
\hline Диканька & 99,6 & 98,7 & 43,3 & 41,5 & 94,1 & 93,7 \\
\hline Василина & 99,5 & 98,3 & 41,8 & 40,2 & 95,1 & 94,7 \\
\hline Смуглянка & 99,3 & 98,5 & 42,5 & 40,6 & 93,6 & 92,8 \\
\hline
\end{tabular}

Посівні якості насіння (чистоту, масу 1000 насінин і лабораторну схожість) пшениці озимої першої репродукції визначали за загальноприйнятою методикою в лабораторії якості зерна Полтавської державної аграрної академії.

Результати досліджень. За роки досліджень показник чистоти насіння у сортів пшениці озимої більшим був у 2011 році й становив 99,399,8 \%. Згідно з вимогами держстандарту ДСТУ 4138-2002, сорти пшениці озимої за чистотою мали кондиційне насіння. У 2012 році показник чистоти насіння у сортів був дещо меншим і в цілому становив 98,3-99,2 \%. Проте за нормами держстандарту насіння першої репродукції досліджуваних сортів також було кондиційним.

За даною ознакою висококондиційне насіння мав сорт Подолянка (99,2-99,8 \%) (див. табл.).

Маса 1000 насінин у сортів пшениці озимої за роки досліджень варіювала таким чином: у 2011 році дана ознака була більшою й становила 41,8-44,4 г; у 2012 році значення даного показника дещо зменшилося (40,2-41,7 г).

За ознакою маси 1000 насінин можна виділити сорт пшениці озимої Золотоколоса (41,7-44,4 г), який характеризувався вирівняним

\section{БІБЛІОГРАФІЯ}

1. Авдоніна Н. С. Значення абсолютної ваги насіння у величині та якості врожаю пшениці / Н. С. Авдоніна / Збірник наукових праць МНДІП ім. М. В. Ремесла, 2003. - С. 56-61.

2. Гаврилюк М. М. Насінництво й насіннєзнавство польових культур / М. М. Гаврилюк. - К. : Аграрна наука, 2007. - 216 с.

3. Дворник В. Л. Вплив агроекологічних факторів на посівні властивості насіння озимої пшениці / і крупним насінням.

За роки досліджень у сортів пшениці озимої лабораторна схожість насіння була відносно високою й становила відповідно: у 2011 році 93,6-95,1\%; у 2012 році - 92,8-94,7 \%. Згідно 3 вимогами держстандарту ДСТУ 4138-2002, насіння першої репродукції у досліджуваних сортів за показником лабораторної схожості було кондиційним.

Найбільша лабораторна схожість насіння спостерігалась у сорту Василина (94,7-95,1%).

\section{Висновки:}

1. Виділено сорт пшениці озимої Подолянка (99,2-99,8 \%) - за показником чистоти та сорт Василина (94,7-95,1 \%) - за лабораторною схожістю, що характеризувалися висококондиційним насінням першої репродукції.

2. Відмічено сорт Золотоколоса за ознакою маси 1000 насінин (41,7-44,4 г), у якого було крупне і виповнене насіння.

3. Насіння сортів пшениці озимої Подолянка, Золотоколоса і Василина можна рекомендувати як посівний матеріал для вирощування на виробничих посівах в умовах Полтавської області.

В. Л. Дворник // Збірник наукових праць МНДІП ім. М. В. Ремесла, 2005. - С. 56-61.

4. Донець М. М. Насінництво з основами селекції: навчальний посібник / М. М. Донець. - К. : Аграрна наука, 2007. - 337 с.

5. Шелепов В. В. Селекція, насінництво та сортознавство пшениці / В. В. Шелепов, М. М. Гаврилюк, М. П. Чебаков [та ін.]. - Миронівка, 2007. $405 \mathrm{c}$. 